Bryn Mawr College

Scholarship, Research, and Creative Work at Bryn Mawr College

Classical and Near Eastern Archaeology Faculty

Research and Scholarship

Classical and Near Eastern Archaeology

1964

\title{
The Date of the So-Called Lysippean Jason
}

Brunilde S. Ridgway

Bryn Mawr College

Let us know how access to this document benefits you.

Follow this and additional works at: https://repository.brynmawr.edu/arch_pubs

Part of the Classical Archaeology and Art History Commons

\section{Custom Citation}

Ridgway, Brunilde Sismondo, "The Date of the So-Called Lysippean Jason," AJA 68 (1964): 113-128.

This paper is posted at Scholarship, Research, and Creative Work at Bryn Mawr College. https://repository.brynmawr.edu/arch_pubs/169

For more information, please contact repository@brynmawr.edu. 


\title{
The Date of the So-called Lysippean Jason ${ }^{*}$
}

\author{
BRUNILDE SISMONDO RIDGWAY
}

PLATES $37-38$

Lysippos of Sikyon, one of the most famous sculptors of antiquity, is also among the most imperfectly known. We are fairly certain that his activity extended from at least 364 to at least 306 B.c., ${ }^{1}$ that he had three sons and many pupils, and that his artistic influence on later sculpture was considerable. Beyond these facts we are in doubt and find ourselves in the uncomfortable position of ascribing to the Sikyonian artist two such basically different statues as the Agias in Delphi, ${ }^{2}$ which retains the conservative two-dimensional stance of Polykleitan works, and the Vatican Apoxyornenos, ${ }^{3}$ with its innovating torsional pose foreshadowing the three-dimensional experimentations of $\mathrm{Hel}$ lenistic sculpture.

On the evidence of such apparent contradiction of styles it has been argued that the original of the Vatican statue is not by the great master but by a later follower." We have, however, Pliny's statement that Lysippos introduced "innovations which had never been thought of before into the square canon of the older artists." could be taken to refer to the slimmer bodily proportions favored by the Sikyonian master, the emphasis on the novelty of the change seems to imply something more than a mere play with numbers. We have, moreover, significant evidence added by the many statues from the end of the fourth and the beginning of the third century which show ex-

\footnotetext{
* The main points of this article were presented in abbreviated form in a paper read at the Sixty-third General Meeting of the Archaeological Institute of America in Detroit. Michigan, on December 30, 1961 (see summary in $A] A 66$ [1962] 199). Throughout my discussion I have tried to give references, not necessarily to the best illustrations, but to those most readily available. Thus Bieber refers to $\mathrm{M}$. Bieber, The Sculpture of the Hellenistic Age (Columbia Univ. Press, 2nd revised ed. I96I); Lippold to G. Lippold in W. Otto, Handbuch der Archäologie III:I (Munich 1950); Lullies \& Hirmer to R. Lullies and M. Hirmer, Greek Sculpture (Ist ed., New York 1957). I am extremely grateful to the German Institute in Athens for permission to publish the four beautiful photographs of the Akropolis Jason which were taken in 1961 at my request and appear here for the first time. I am also indebted to colleagues and friends for suggestions and revision of my text, and most of all to Professor Rhys Carpenter who taught me all I know about Greek sculpture and whose influence is ever present in my approach and thinking.
}

periments with torsional motion. Since at least some of them can safely be attributed to Lysippos' pupils, it may be assumed that the Lysippean innovation mentioned by Pliny consisted in representing figures moving in a variety of planes, and that the pupils merely carried to ultimate development the axial rotation started by the great master himself. Whoever the initiator, for the purposes of the present paper it suffices to acknowledge that early Hellenistic compositions developed variations of this spiraling motive in both seated and standing figures. The Tyche of Antioch by Eutychides ${ }^{6}$ and the Fanciulla d'Anzio, ${ }^{7}$ probably after an original by Phanis, find parallels in the unattributed Girl in the Conservatori ${ }^{8}$ and the dancing Faun from Pompeii. ${ }^{\circ}$

Aside from this torsional stance, the Apoxyomenos' position itself is three-dimensional, effectively suggesting the enclosure of space. By stretching one arm forward and across toward the other, the statue encircles a definite spatial area in a wedgelike composition that pierces the purely frontal box occupied by earlier figures. Whether or not a Lysippean creation, the Vatican athlete therefore represents the conquest of three-dimensional principles and the end of a long and slow sculptural development toward such three-dimensionality. ${ }^{10}$

Among the statues displaying the same space-en-

1 For a full discussion see Marcadé, signatures I 66.

2 Bieber fig. 76.

3 Bieber figs. 74-75.

4 See Ch. Morgan, "The Style of Lysippos," Hesperia Suppl. 8, 228-234. On the other hand, E. Sjöqvist, "The Early Style of Lysippus," OpusAth I (1953) 87-97, tries to reconcile both attributions, stressing the conservatism of Lysippos' early works, corroborated by Cicero's quotation that no men, but Polykleitos' Doryphoros had been his master and teacher (see especially pp. $9 \mathrm{I}$ and 95 ).

5 Pliny NH 34.65, trans. Jex-Blake. R. Carpenter, Greck Sculpture (Chicago Univ. Press 1960, henceforth quoted as Carpenter) 169 , has been more explicit: "a new and hitherto untried motive for converting the four-sided poses of the older masters."
'Bieber fig. I02.
7 Bieber figs. 99-100.
8 Bieber fig. ror.
0 Bieber figs. 95-96.
10 This development can be summarized thus. Greek sculp- tors tried to impart an effect of three-dimensionality to their 
closing formula of crossing arms is one of a youth binding his sandal (although some authors believe that instead he is untying it), who has been variously named and explained, but is perhaps best known as "the Sandalbinder" or "the Jason." This latter nickname derives from the story that the famous hero had first appeared in the presence of King Pelias with only one shoe on, as foretold by an oracle, having lost the other in crossing a river. Against this identification, however, stands a copy of the statue in Munich ${ }^{11}$ which shows the second sandal on the ground. ${ }^{12}$ Similarly posed figures appearing on coins ${ }^{13}$ and gems ${ }^{14}$ are characterized as Hermes, and an epigram by Christodoros ${ }^{15}$ describes a statue in the Lauseion at Constantinople as Hermes tying his shoe, "eager to start on his way" in obedience to the orders of his father. ${ }^{16}$ But none of the extant copies of our work has any attribute of Hermes preserved, and minor variations can also be observed in the stance of the engraved figures. The statue may well be that of an athlete preparing to depart from the palaistra (were his action to be interpreted as the binding of the sandal), or quickly loosening his shoe to answer a call from the racecourse, and ready to leave the apodyterion. The various extant replicas and adaptations of the original bronze seem to indicate that, whatever its initial significance, the composition became in time a favorite ornament of gardens and gymnasia.

works by several means, and especially by visually enclosing space in their compositions. At first such space coincided with the plane encompassing the figure, even though it surmounted or flanked it. This stage is exemplified by Polykleitos' Kyniskos (Lippold pl. 60:1) and Diadoumenos (Lippold pl. 59:2). Later, this encased space lay outside the human figure itself, mostly parallel to and in front of it, as we see in the so-called Oil Pourer (Lippold pl. 78:1-2) and the Praxitelean Hermes of Olympia (Lullies \& Hirmer pl. 220), wine-pouring satyr (Bieber fig. 15) and the Marathon Ephebe (Lullies \& Hirmer pl. 210). Oil, wine, ribbons, even glances, together with body and arms, here formed one of the boundaries of a roughly rectangular area almost added to the frontal aspect of the figure. The body contributed partly to the creation of such space (notice, for instance, the partial torsion of the Oil-Pourer, whose right shoulder is thrown backward as the pouring hand rises), but mostly presented a lateral displacement hardly affecting the area enclosed in front of the statue. Finally, with the Apoxyomenos, the body revolved in the space itself, which was therefore not merely present in front of the figure but was also all around it.

For a more extensive treatment of this development see alss) Carpenter, I64-I 75 . He, however, denies Praxiteles' contribution to it.

11 Others have been restored after it.

12 Even more improbable is the supposition that the youth
Only three main replicas of the entire statue are known $^{17}$ (here listed in order of importance):

I) Copenhagen, Ny Carlsberg Glyptotek (I.N.2798); formerly in Lansdowne House, London, and therefore often mentioned as the Lansdowne Jason.

Height: r.45 m.; with base r.62 m. Pentelic marble.

Restorations: nose, part of the r. eyebrow, an area of the hair above the $r$. ear, a piece of the neck, $r$. forearm, r. foot, rock, support, most of the plinth (once restored with additional sandal and plowshare after the replica in the Louvre, now removed), 1. upper arm from shoulder to elbow, l. hand, parts of the cloak and buttocks, l. lower leg between knee and ankle.

The 1. foot and the adjacent part of the plinth are antique. The head has been broken off and reconnected to the body by a narrow modern strip, but it is antique, of the same marble and workmanship as the body, and belongs to the statue, as proved also by the unfinished replica of the Jason in Athens. This seems to be the only complete copy with pertinent head.

The 1 . forearm is preserved unrestored and seems to indicate that in the original bronze it rested on the youth's 1 . knee, instead of stretching toward the r. foot, as restored in the other two versions.

The statue was found by Gavin Hamilton in 1769 , in Hadrian's Villa at Tivoli. It was bought by the Lansdowne Collection in $177^{2}$ and stayed in London until 1930, when it went to its present location.

Selected bibliography: Michaelis, Ancient Marbles $464-466$, no. 85 ; described as a replica of the statue of Hermes tying his sandal in the Louvre.

F. Poulsen, Catalogue of the Ny Carlsberg Glypto-

represents the Athenian Theseus or the hero Perseus; the nickname of Roman Cincinnatus has long been discredited, since it was based on the plowshare added by a modern restorer to the copy in the Louvre.

${ }^{13}$ For numismatic references see F. Johnson, Lysippos (Duke Univ. Press 1927, henceforth quoted as Johnson) I7I nn. 3537.

${ }^{14}$ Among recent publications of such gems see D. M. Robinson, "The Robinson Collection of Greek Gems," Hesperia Suppl. 8, p. 317, no. 21, pl. 42, 2 1а.

15 Ant.Pal. 2.297-302, Ekphraseis; text and translation (by Paton) in Johnson, 316-317.

${ }^{16} \mathrm{Ch}$. Picard, "Trois bas-reliefs Eleusiniens," $B C H \quad 55$ (I93 I) I I-45, pl. I, publishes an unfinished relief from Delos showing, besides other figures, Zeus seated faced by Hermes tying his sandal, ready to convey to Hades Zeus' message to release Kore. The pose of the Hermes is compared with that of the Jason. For further discussion of the Delian relief, see infra.

${ }^{17} \mathrm{~W}$. Fröhner, Notice de la sculpture antique du Louvre (1886), K. Lange, Das Motiv des aufgestützten Fussen in der antike Kunst und dessen statuarische Verwendung durch Lysippos (Dissertation, Leipzig I 879 , henceforth quoted as Lange), and Johnson, all list four such replicas because they include the Vatican statue which I shall discuss below together with the variants of the Jason. 
tek (Copenhagen 195r) 204, no. 273a. Described as sandal-tying Hermes, though "it is not improbable that the statue may also have been used as an ordinary picture of a young sportsman in the Palaestra."

Johnson, Lysippos I70-177, passim, pls. 30-31.

Arndt, Glyptothèque Ny Carlsberg I77-181, figs. 96-98.

2) Paris, Louvre (pl. 37, figs. I-2)

Height: 1.77 m. Body in Pentelic, head in Parian marble.

Restorations: tip of nose, lower lip, chin and occiput. L. arm and shoulder, half of the r. forearm, r. hand, r. leg to just above the ankle, part of the drapery, two toes of the r. foot, a piece of the sandal strap. R. leg broken and restored with the addition of five modern sections. Two modern insertions also in the abdominal area and two more in the r. arm. A break along the back of the $1 . \mathrm{leg}$ is filled with modern pieces.

The head is antique and very well fitted at the base of the neck, but the joining was probably done even before the statue reached France. It is accepted by some authors as belonging to the statue, although made of different marble. Other ancient pieces are known in which the head is made of stone better than that used for the rest of the figure, but usually such statues represent draped personages, and the transition from one material to the other is logically explained as a contrast between drapery and flesh. The head at present on the Louvre Jason is strikingly similar to that of the Borghese Warrior and, although its face is narrower and its hair more tidily arranged, it bears some resemblance to the head of the Lansdowne repli$\mathrm{ca}$, which belongs to its body.

The Louvre replica comes from Rome, Palazzo Savelli, in the area of the Theater of Marcellus, later Villa Montalto (Negroni). Louis XIV bought it from the Montalto collection in 1685 and moved it to Versailles, where it stayed for a long time before entering the Musée Napoléon, whence it passed to the Louvre.

Selected bibliography: Notice des statues, bustes et bas-reliefs de la Galerie des Antiques du Musée Napoléon (Paris I801) 86-87, no. I08; described as "Jason, dit Cincinnatus."

Fröhner, Notice de la sculpture antique du Musée National du Louvre (Paris 1886) 210-211, no. 183. Described as "éphèbe grec, dit Jason, dans l'attitude d'Hermès" tying his sandals.

Encyclopédie photographique de l'art (TEL III, Paris 1938) pl. 196.

Arndt, Glyptothèque 180-181, figs. 108-1 I0; 3 views of the head.

$\mathrm{BrBr} 67$.

Johnson, Lysippos I70-I77, passim.

3) Munich, Glyptothek König Ludwigs I (Gl. 287) (pl. 37, fig. 3)

Height: $\mathrm{I} .43 \mathrm{~m}$.; with plinth $\mathrm{I} .53 \mathrm{~m}$. Body in Pentelic, unrelated head in Parian marble.

Restorations: both arms, except r. hand holding piece of sandal strap; whole r. leg, 1. thigh, front half of $r$. foot and outer part of plinth. Whole ancient surface destroyed.

The head is ancient but alien, a Roman copy of a youthful Apollo type of the fourth century B.C. (I therefore omit a list of its restorations).

This statue is important because its $r$. hand is unrestored and therefore should reproduce the position of the original (all the other replicas are restored in this detail). The presence of the sandal strap between the fingers is interpreted by some authors as definite evidence that the youth is binding, and not loosening, his shoe (cf. Johnson I73; Arndt I78ff).

According to Wagner's investigations, this statue was found in the late 1780 's by Conte Marefoschi at Tivoli, in Hadrian's Villa. Through Jenkins, an English art dealer in Rome, it passed to Duca Braschi Onesti, who had it restored by the sculptor Franzoni. In I809, through Dillis, it was bought from Braschi by King Max I, and was first placed in the Akademie der bildenden Künste in Munich, whence it reached the Glyptothek König Ludwigs I in 1819 .

Selected Bibliography: H. Brunn, Beschreibung der Glyptothek K. L. I (Munich 1868) 195-196, no. I51, described as Hermes tying his sandal.

Furtwängler, Beschreibung Glypt. K. L. I (Munich 1900) 291-294, no. 287, same description.

Sieveking and Weickert, Fünfzig Meisterwerke der Glyp. K. L. I (Munich 1928) pl. 25, described as "Sandalenlöser."

\section{Johnson, Lysippos r70-177, passim.}

Besides these complete replicas, we possess three fragmentary torsos and two, perhaps three, reproductions of the head.

I) Perinthos, fragmentary torso

Height: not given, but piece described as lifesize. (?) marble.

Missing: head, 1. shoulder and arm, r. forearm, both legs from middle of thigh.

The torso is turned to the 1 . so sharply that deep folds appear in the stomach area. Traces of drapery are preserved over the $r$. leg. The work is defined as hard and stiff.

Selected bibliography: the only detailed reference and illustration (a drawing) of this piece, to my knowledge, appear in ÖJh I (1898) Beibl. cols. I I9I20, fig. 32 (E. Kalinka, "Antiken zu Perinth," no. 2I).

Johnson, Lysippos I7r.

2) Side, Pamphylia, fragmentary torso

Height: not given, but piece described as under lifesize. (?) marble.

Missing: (my inferences, drawn from illustration) part of the head and entire face from point of attachment to neck; 1. arm; r. forearm; l. buttock (?) and leg; r. leg except for a fragment from the upper surface of the raised thigh.

The torso stood in a niche of the upper storey of an 
elaborately decorated wall in Building M. For want of epigraphical material, the structure, investigated in r949-5I, has been tentatively classified as a gymnasiumlibrary with a special room for the imperial cult. Other statues from the same decorative complex are said to reproduce fifth and fourth century B.c. originals; their high polish and drillwork, together with the architectural details of Building $\mathrm{M}$, date them in the Antonine period.

Selected bibliography: A. M. Mansel, Die Ruinen von Side (Berlin 1963) i 16 , and fig. 91 at p. i14.

A brief account of the work on Building $M$ was given in $A A$ (1956) cols. 58-69; see especially cols. 65-66 for the sculptural finds, though the Jason's replica is not specifically mentioned.

3) Athens, Akropolis Museum (1325) unfinished torso (pl. 38, figs. 4-7)

Height: preserved, $0.53 \mathrm{~m}$. (lifesize proportions). Across shoulders $0.45 \mathrm{~m}$. Pentelic marble.

Missing: both legs from points of attachment to torso (the piece ends in a slanting break level with the beginning of the pubic hair), both arms except for stumps of the upper arms (biceps level). The head is broken at the base of the neck, but enough original surface remains to show that it joins the torso. In the face, the nose and upper lip are badly battered. The whole surface of the work is rough and obviously unfinished.

The torso once stood in the north wing of the Propylaia, to the r. of the entrance to the Pinakotheke, together with other ancient pieces whose original location is not known; we cannot therefore infer that the Jason came from the Akropolis. It was moved to the Akropolis Museum around 1884. The pertinent head was found in that museum by Studniczka in I 886.

Selected bibliography: the most extensive description is given by Milchhöfer in a note quoted by $\mathrm{L}$. Schwabe, "Wagenlenker," IdI I ( 1886) I70 n. I8, under the assumption that the torso represented a charioteer. The correct attribution was made by Studniczka upon discovery of the head, "Zusammensetzungen in Akropolis Museum," $A M$ I I ( 1886 ) 362-364 no. 7 , pl. Ix, I.

Head illustrated in $E A 733 / 734$ (text p. 28, Arndt). C. Blümel, Greek Sculptors at Work (trans. Holland, London 1955) 59 and 62, fig. 48 at p. 63.

The importance of this torso lies especially in the preservation of the head, whose connection with the body cannot be denied in view of its unfinished state. Besides confirming the pertinence of the head on the Lansdowne replica, the Athenian piece allows the attribution of the following heads:

I) London, British Museum (no. 1785) so-called Fagan Head

Height: I' $5^{\prime \prime}$. Parian marble.

Restorations: nose, ears, bust. Also small repairs in wax. The head was probably broken off a statue.
The piece was found by Robert Fagan during his excavations at Ostia around 1795. It was afterwards in the collection of Samuel Rogers, and in 1856 was bought by the British Museum.

Selected bibliography: Smith, A. H., Catalogue of Sculpture in Br. Mus. III (London Ig04) IIg.

Arndt, Glyptothèque, figs. 99-100.

Johnson, Lysippos pl. 32 в.

2) Copenhagen, Glyptotek Ny Carlsberg (I.N.572) Height: (of head alone) $0.26 \mathrm{~m}$. The head is mounted on an unrelated bust and neck. (?) marble.

Restorations: nose, central portion of upper lip, parts of ear rims, curl above center of forehead, part of hair from crown toward front, part of hair between neck and head.

The curls are more prominent and disarranged than in other copies.

The head stood once in the Villa Borghese, where it was called "Genio del Popolo Romano."

Selected bibliography: Arndt, Glyptothèque pls. 128I 29, pp. I77-1 81 ; described as Hermes tying his sandal. F. Poulsen, Catalogue N. K. Gl. 203 no. 273.

3) Turin (?)

Height: $0.27 \mathrm{~m}$. ; height of face $0.175 \mathrm{~m}$. Greek marble.

Restorations: top of nose. The head appears very square, with the so-called Michelangelo bar above the brows strongly marked.

Selected bibliography: the only detailed description and illustration appear in A. J. B. Wace, "Some Sculptures at Turin," JHS 26 (1906) 239-240, no. 4 pl. xvi. He defines the head as "either a second-rate original, or else a fair copy of a good marble original" (while usually the original of the Jason is supposed to have been of bronze). The author suggests that the "nearest parallel is perhaps the head of the so-called Jason," but the resemblance is by no means indisputable.

Johnson, Lysippos I77, defines it "apparently a portrait."

Since all these replicas of body and head have been extensively restored we must visualize an imaginary statue by eliminating all additions. and combining all the features preserved by extant copies. What emerges as the product of this mental alchemy is the figure of a naked youth, lifesize, powerfully built, with relatively small head and long limbs, whose right foot rests on a rocky elevation, thus causing the knee to bend almost at a right angle. The body of the young man is bent forward (since the right hand stretches toward the raised ankle) and describes a long slow curve from the top of the shoulders to the left foot, which rests flat on the ground. His left arm, wrapped in his cloak, leans on the right thigh, and his head turns abruptly to the left, toward the onlooker. 
The replica closest to the bronze original is probably the one in Athens, which, in spite of its unfinished state, shows excellent workmanship and has the advantage of being unaltered by modern restorations. The position of the right hand, holding the sandal strap near the right foot, is given by the Munich copy, and the Lansdowne replica indicates that the left arm rested on the bent knee. The presence of drapery around this arm and on the thigh is confirmed by almost all replicas, especially by the torso in Perinthos which is unrestored. A composite modern bronze, similar to our imaginary reconstruction, ${ }^{18}$ is in the Stettin Municipal Museum (after a cast in Munich), and is illustrated by Arndt, Glyptothèque I77, fig. 95 .

Several adaptations and modifications of this composition are known. K. Lange ${ }^{19}$ suggested that five statues (our nos. 2-6 infra) derived from the same original: a resting athlete by the same master of the Sandalbinder, meant as a pendant to the Jason and as ornament for a palaistra. These five works share the general position of the body, with the left, rather than the right, foot raised and head turned to the right, thus forming a mirror-image of the Jason's pose; but they also present so many differences in details that I hesitate in grouping them together except as variations on the general theme introduced by the Sandalbinder.

Two Roman portrait statues excavated in recent years have reopened the question of attribution to an independent original creation. The monument from Cassino (infra, no. 7) is published by G. Carettoni, ${ }^{20}$ who believes it closest to the bronze original, and uses it to subdivide Lange's list into two groups, each stemming from a different prototype. The Cassino statue would belong to the first group representing an athlete in a pose of momentary rest and vigilant anticipation, with body and head rotating frontward, feet almost at right angles to each other, and wrists crossing. Group II would include ephebes characterized by younger age, head and body fully in profile, arms uncrossed and in an oratorial pose. Carettoni believes that Lysippos created the prototype for his Group I, and that the original for his Group II stems from the same artistic current and was probably meant as pendant to the first composition. He thus ends by attribut-

18 Except for the right hand, which copies the modern one of the Lansdowne replica.

19 op.cit. (supra, n. 17) 13-18.

20 "Replica di una Statua Lisippea rinvenuta a Cassino," ing to Lysippos three similar but independent types: the Jason, the Resting Athlete and the Conversing Ephebe.

The second Roman statue (no. 8 infra) comes from Ostia. It is very similar to the Cassino monument, but R. Calza ${ }^{21}$ derives different conclusions from it. She agrees in ascribing to Lysippos the "sandal-binding Hermes"-our Jason-but believes that the "Resting Athlete" (and implicitly the talking Ephebe) was created as a re-elaboration of the fourth-century composition in a period when such "Spiegelbilder" were highly fashionable: during the Neo-Attic movement around 40 B.c. This new creation would represent Theseus, though often used as a stock body for portrait heads. Against Carettoni's description of a fully virile but lean anatomy and a vigilant pose, Mrs. Calza stresses the heavy ponderation and relaxation of the composition, with musculature well advanced over Lysippean renderings and "baroque" voluminous drapery.

The works discussed by the two Italian archaeologists in conjunction with the portrait monuments are reliefs clearly patterned after the Jason's motif, or statues in the round imperfectly known through drawings and extensively restored. I consider them more or less uninspired adaptations of the Sandalbinder in reverse pose, and append here a list and descriptions of the monuments known to me which can share such qualification.

I) Vatican, Gall. Cand. I, 7, statuette, restored as Sandalbinder

Height: without plinth $0.50 \mathrm{~m}$; of head, $0.09 \mathrm{~m}$. White marble.

Restorations: 1. forehead with part of lid, nose, upper lip, chin, half the neck, arms except for attachments, r. leg from middle of thigh, 1 . leg with 1 . buttock and piece of hip, support, plinth. The body is strongly polished; no certain ancient surface preserved. The $r$. side of the head has been retouched.

The statue, as restored, forms a mirror-image of the Jason. However, since the arms and the 1 . leg are modern and built intentionally after the Sandalbinder in Paris, their original position might have been different. The piece was bought from the sculptor Franzoni (who repaired the Munich replica of the Jason around the same period, see supra, no. 3) in 1789.

Selected bibliography: the statue is listed as one of the replicas of the Jason by Michaelis (p. 465), Lange

MemPontAcc 6:1 Ser. 3 (1942) 53-66.

21 "La statua-ritratto di C. Cartilio Poplicola," in M. F. Squarciapino, Scavi di Ostia III:1, Le necropoli (Rome 1958) 221-228. 
(p. 2) and Johnson (p. I7r: "a fairly accurate copy so far as preserved, except that it is reversed").

Lippold, Vat.Kat.III:2, Io8 no. 7 (6), pl. 52, considers it an independent creation contemporary with the Jason, while Schuchhardt (review of Lippold in Göttingische Gelehrte Anzeigen [1960] 213, p. 177) rightly, as I believe, calls it a free version or adaptation of the Jason.

2) Capitoline Museum, Ephebe

Height: 1.845 m. Luna marble.

Restorations: nose, r. hand and wrist (the r. arm is broken at the shoulder and refitted with an inserted piece; broken also at the elbow and rejoined with plaster), l. hand, front half of $r$. foot, l. leg from knee with rock and plinth, small patches in drapery. The statue is made in two pieces joined together below the roll of drapery at the waist. The head is in one piece with the body.

The youth is shown in a mirror-image of the Jason, with his 1 . foot on a rock and his 1 . arm on his knee. The drapery, instead of being only around this arm, as in the Jason, is also wrapped around the lower torso. The r. arm is raised in an "adlocutio" pose; since, however, the limb was extensively broken, this restoration is not absolutely certain. Clarac and Lange believed that the original position implied the crossing of the wrists, while Carettoni stresses that the r. arm is ancient up to the wrist and therefore the gesture is correct. The youth's head, surely pertinent, does not turn, but bends slightly and looks forward. The feet lie along almost parallel lines, and therefore the r. leg appears in profile and the body shows little or no torsion.

The piece, of Hadrianic workmanship, comes from a chamber of the substructures in the so-called Poikile of Hadrian's Villa at Tivoli. Found in I742, it was acquired by the Museum in I744. It has been suggested that it represents Hermes Agoraios, an Athlete resting or an Ephebe talking. Kekule believes that it is an adaptation of the Jason, while Lange (p. I5) lists it as $E$ among the replicas of his "Resting Athlete." The realistic treatment of the hair might qualify it as a portrait statue. It differs from all the others in the particular arrangement of the mantle.

Selected bibliography: Stuart-Jones, Cat.Cap.Mus. 288 no. 2 I, pl. 70 (with complete bibliography up to date).

$\mathrm{BrBr} 387$.

S. Aurigemma, Villa Adriana (Rome ig6r) fig. 36, p. 62.

Carettoni, MemPontAcc 6:I (I942) fig. 5 at p. 59; no. 5; part of his Group II.

3) Paris, Louvre, statuette of an athlete

Height: I. 359 m. Greek marble.

Restorations: r. arm with shoulder, most of 1 . forearm, r. leg with knee, l. leg from below the knee, small rock, small portion of drapery. The head seems unrelated.

The piece is again a mirror-image of the Jason, with
1. foot on rock (see however list of restorations), and the 1 . arm on the thigh. The r. arm, raised and bent level with the shoulder, is wholly modern and wrongly restored. The head is turned back to the right, rather than frontward as in the Sandalbinder; it may be unrelated but its position, according to Carettoni, is correct. The torso appears more frontal than in the Jason. The drapery rests entirely on a tree trunk-obviously a support-behind the r. buttock and leg of the statue. From Villa Borghese.

Selected bibliography: Clarac III, pl. 27I, no. 2194, text v. 5, p. 124 (a drawing).

Lange, $D$, pp. I4-I 5 .

Furtwängler, Meisterwerke 524-525: "eine spätere Schöpfung des Skopas" (together with no. 4 infra). Carettoni, op.cit. 58, fig. 3 (after Clarac) no. 3 . Part of his Group I.

De Villefosse-Michon, Cat. des marbres ant. du Louvre (I922) I32, no. 2407 (cited by Carettoni).

4) Paris, Louvre, statuette of an athlete

Height: 1.392 m. Body of Carrara, head of Parian, marble.

Restorations: arms from below the deltoids, r. knee, 1. leg between knee and ankle, drapery with support, small rock. The head seems unrelated though probably correctly fitted, as proved by comparison with no. 2 supra. Drapery and support are restored as in no. 3 supra.

A mirror-image of the Jason, with 1. foot on rock and 1. arm on thigh. The pose, with head and body fully in profile, differs from no. 3 , but since no. 4 also comes from Villa Borghese, it is suggested that they were matching pieces.

Selected bibliography: Clarac III, pl. 271, no. 2193, text. v. 5 p. I24.

Lange, $C$, p. I4.

Furtwängler, Meist. (see no. 3, supra).

Carettoni, ibid. fig. 4 (after Clarac) no. 4. Part of his Group II.

De Villefosse-Michon, ibid. no. 2408 (cited by Carettoni).

5) Rome, Courtyard of Palazzo Altemps at S. Apollinare, gladiator?

Height: without head, $1.85 \mathrm{~m}$. Greek marble.

Restorations: both arms from below the deltoids including the 1 . hand and the corresponding piece of drapery, r. thigh and leg, fragments of drapery and of the 1 . leg. The head is unrelated and half of the neck is restored, but the direction seems certain. The rock is ancient and has been inserted into the modern base.

The statue shows a youth with both arms crossed over the 1 . thigh (but this modern restoration might be incorrect), his head raised upward to the right, some drapery falling on the 1 . thigh, and a more frontal pose than the Jason, of which it is a mirrorimage. It has been considered a gladiator, a "Resting Athlete" and an adaptation of the Alexander Rondanini. 
Selected bibliography: Clarac V pl. 854 D no. $221 \mathrm{I}$, text v. 5 p. 135 .

Lange, $B$, p. I4.

F. Matz and F. von Duhn, Antike Bildwerke in Rom I (1881?) 312-313 no. 1083.

Koepp, 52 Winkelmannsprogramm (I892) note 50. Carettoni, op.cit. 57 fig. 2 (a real photograph); no. 2, part of his Group I.

6) Probably Paris, Louvre, so-called Theseus

Height: 1.32 m. Parian marble.

Restorations: r. leg with knee, 1 . leg without the knee, tree trunk, rock and plinth. Head, hands, feet and genitals damaged. The head is ancient but alien (?), probably a portrait.

The youth rests his 1 . foot on a rock and crosses both arms over his 1 . thigh. The 1 . arm is wrapped in drapery. Mirror-image of the Jason.

The statue, probably from Greece, was once in the Napoleon Museum; it was then moved to Fontainebleau, but was returned to the Louvre in the last quarter of the last century, and it seems to have been in the Louvre magazines at the time of Lange's dissertation, according to a letter quoted by him (p. 13).

Selected bibliography: Notice du Musée Napoléon (see supra no. 2, p. II5) no. 87, pp. 69-70.

Carettoni, op.cit. 56 fig. I (drawing after Piranesi) no. I, probably part of his Group II.

Lange, $A$, p. I 3 .

F. P. Piranesi, Ant. du Musée Napoléon II (1804) I I Iff; pl. 52 (quoted by Carettoni).

E. Q. Visconti, Opere Varie IV (1831) I56ff, pl. 21 (a drawing), 320 no. 87 (quoted by Carettoni).

7) Naples, National Museum, from Cassino. Roman portrait statue

Height: (as restored) $2.02 \mathrm{~m}$. Greek (Pentelic?) marble.

Missing: r. leg from below knee, rear part of r. foot, heel of 1 . foot with ankle, fingers of $r$. hand, blade of sword in 1 . hand (only hilt remains), most of plinth, support under l. foot, lower portion of mantle on 1 . thigh. The statue shows various minor abrasions. In the head, most of the nose is missing, the rims of the ears are chipped.

Found in ten fragments in 1936, in a deep shaft of the stage building of the theater in Cassino. Mirrorimage of the Jason.

The statue shows a naked man, his head turned toward the r. shoulder and upwards. His body is slightly bent forward, his 1 . leg rests on a support, while his $r$. is on the ground. His 1 . forearm is on the 1. thigh, over the bent knee; in his 1 . hand he holds a sword; his $r$. hand rests over the 1. A richly draped mantle falls over the 1. thigh, hanging free on both sides. The portrait head favors a date toward the end of the Republic and the beginning of the imperial period. The excavators suggest that it might represent C. Ummidius Durmius Quadratus, builder of the theater, who, under Augustus, was a legate of Tiberius.

Selected bibliography: NSc (1939) I3I-I33.
$A A$ (I94I) cols. 560-564, fig. 93 (head). Mentioned as an adaptation of a "resting hero," the Alexander Rondanini, the Jason or Theseus, after a prototype by Lysippos or Leochares.

Carettoni, op.cit. 53-66, pls. I-4.

R. Calza, op.cit. (supra, n. 21) passim and pl. 47:2.

8) Ostia Museum (no. I2I), Roman statue, probably a portrait

Height: (at present) $1.95 \mathrm{~m}$. (as given in Scavi di Ostia III 221, probably including base, because given as $\mathrm{r} .88 \mathrm{~m}$. in $\left.A A \mathrm{r} 93^{8}\right)$.

Italian $(A A$ I 938$)$ or Hymettian (Ostia III) marble.

Missing: Head, r. arm, 1. hand, upper part of 1 . foot; 1 . leg and drapery deeply chipped.

A naked man is shown, mirror-image of the Jason. His 1 . foot rests on a cylindrical support bearing an inscription with the name of C. Cartilius Poplicola. His l. arm leans on his 1 . knee; the missing r. arm probably crossed the 1 . A large fringed mantle covers the 1. upper arm to the shoulder and falls in broad folds over the thigh and along the 1 . leg down to the base. The extant parts of neck and nape with traces of short hair suggest that the head was turned to the right.

The statue was found in 1938 on the steps of the Temple of Hercules in Ostia.

Selected bibliography: R. De Chirico, R. Calza, $A A$ (1938) col. 657, fig. I7; mentioned as a votive dedication by Poplicola and dated in the early Antonine period (cf. also Le Arti, infra).

R. Calza, Ostia III 22I-228, pls. 44-47; interpreted as a portrait dedicated by the people of Ostia in honor of Poplicola and during his lifetime, around 40-30 B.c. After contemporary Neo-Attic creation representing Theseus. The identification with the Athenian hero is made on the strength of the sword preserved in the hands of the similar Cassino statue, and because such a subject would be appropriate for a statue dedicated in a temple of Herakles, a great friend of Theseus.

G. Calza, Gnomon (1938) 6o7; Le Arti I (1938-39) 389.

R. Calza, Museo Ostiense (Rome I947) 25 no. I2I (pl. 4o, appearing in center of room).

Carettoni, op.cit. fig. 6, p. 6o. Part of his Group I.

9) Naples Museum, from Pompeii. Statuette of a sat$\mathrm{yr}$, as fountain ornament

\section{Height: not given. Marble?}

This young satyr stands on his r. leg with his 1 . foot on a rock. Both his hands cross over the raised knee, holding a water pipe and the end of the nebrys which covers part of the l. thigh and the top part of the rock. His head is turned to the right. Mirrorimage of the Jason.

Found in Pompeii, Reg. I (Casa del Conte di Torino) in the center of the impluvium.

Selected bibliography: NSc 2 (1905) 249 fig. 4 and 250 (cf. also fig. 2 at p. 247 for plan of house and location of statuette). 
Io) Naples Museum, statuette of a satyr with a wine skin

This piece is known to me only through a mention by Carettoni, op.cit. who describes it as similar to our no. 9, with r. foot raised and holding a wine skin against it.

The satyr from Pompeii is a fountain ornament and, together with no. Io, is the farthest removed from the prototype, with which it shares only the pose in reverse. The remaining eight human figures seem to experiment with the pose in two directions: one emphasizes the profile stance of the body, to the extent of eliminating the characteristic turn of the head and aligning the supporting leg with the raised foot (nos. 2, 4); the other tends to open the pose, even turning the head backward and placing the two feet at right angles (nos. 3, 8). Carettoni indeed points out that the main view of the Cassino statue (no. 7) is from the side (of the base-his pl. I), although the anatomical development of the back is, disproportionately, twice the dimension of the chest. In the Ostia statue (no. 8) the pose of the Jason seems contaminated by that of the Lateran Poseidon or the Alexander Rondanini, ${ }^{22}$ so that no true profile view of the statue exists, as proved by the illustrations in Ostia III. The photograph for pl. 44 was taken parallel to the front of the statue's base, yet no part of the man's back shows; the two figures in pl. 45 are aligned with the base's side, yet they fail to give a true profile view of the human body. This position is thus almost a reversal of the Jason's, as I shall discuss below.

Other statues exist, which merely retain the Sandalbinder's stance, with raised foot and arm (or arms) crossed over the bent knee. Their nature has changed entirely since we deal here with female figures, variously described as nymphs, muses or Aphrodites, of which a selected list is given below:

I) Rome, Vatican, Gall. Cand. III, II (129)-Lippold, Vat. Kat. III: 2 pp. 234-235, pl. 108. Statuette of nymph (?), foot on hydria. Mirror-image of Jason's pose. Fountain figure-Roman work.

2) Rome, Conservatori, Sala Monum. Arcaici 29Stuart-Jones, Cat., p. 226, pl. 851. Statuette of Muse (?). Mirror-image of Jason's pose. 2nd cent. A.D.

3) Broadlands-Michaelis no. I2; EA 4855a. No date given.

22 Mrs. Calza's claim that the type of the Ostia statue is a late Neo-Attic creation may thus be right.
4) Kyzikos, Aphrodite (?)-EA r353. No date given. Mirror-image of the Jason's pose.

5) Rome, Antiquarian Market, RM 63 (1956) pls. 1320. Statue found near Tiber; nymph, muse or personification. Mirror-image of Jason's pose. End of 2nd cent. B.c.

6) Rhodes, Museum, ClRh 5:I (1931) no. 2, pp. 16-22, pl. II, figs. 9-I2. Same pose as the Jason, considered product of Rhodian school flourishing between $3^{\text {rd }}$ and ist cent. B.c. Aphrodite or nymph.

7) Milan, BdA 39 (1954) S. Iv, pp. 97-106, figs. r, 3-6. Same pose as the Jason; considered Hellenistic original, possibly of the and cent. B.c., having analogies with works of Rhodian school. Semidraped Aphrodite or nymph with balteus.

There are, of course, many other monuments representing figures in the same general position, but they are more specifically characterized as Poseidon, Zeus or other divinities. ${ }^{23}$ Furthermore, the stance or the general approach to the composition varies, and these differences are of importance in determining the chronological position of the Jason and its variants as contrasted to these other works. I shall discuss some of them individually below.

While all the adaptations or derivations of the "Jason-motif" seem to be uninspired, more or less mediocre works, often smaller than lifesize, there is general agreement that the original of the Sandalbinder must have been one of the masterpieces of antiquity. Not only are his replicas all of large scale, but their workmanship is generally good, in some cases outstanding, as for instance in the copy in Athens.

The elongated body of the youth, his relatively small head, and especially the typical three-dimensional pose of one arm carried horizontally toward the other which repeats the formula employed in the Vatican Apoxyomenos, have long suggested the attribution of the statue to Lysippos. Johnson, in his monograph (p. I74) gives lists of scholars accepting such an attribution, and lately two authorities on Hellenistic art-Lippold in his Handbuch der Archäologie, ${ }^{2+}$ and Dr. Bieber in her Sculpture of the Hellenistic Age $e^{25}$-have pronounced themselves in favor of this opinion. Other archaeologists, ${ }^{26}$ however, find the anatomy of the Jason too advanced for a Lysippean creation, and

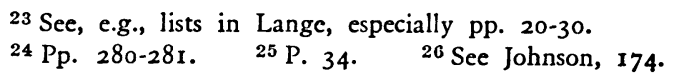


suggest that the statue is the work of one of the master's pupils, from the beginning of the Hellenistic period. Dickins ${ }^{27}$ affirms that the Sandalbinder reveals "new details in abdomen, groin, and the inner side of the thighs, unknown" to Lysippos. Johnson, ${ }^{28}$ from an analysis of the body and face of the Jason against those of the Apoxyomenos, decides that the Sandalbinder is more developed than the Vatican statue and also differs morphologically; he suggests Euthykrates, a member of the Lysippean school, as the most probable author of the piece. Most recently, J. Dörig, who has devoted considerable study to works by Lysippos and his pupils, has advocated a date in the early third century в.c. for the Jason. ${ }^{29}$ I recognize the presence of some indisputable Lysippean echoes in the Sandalbinder, but I find myself at variance with both schools of thought. In my opinion the statue is not the creation of the Sikyonian master or his circle, but is an independent composition of the latter half of the second century B.c.: a period characterized by eclectic tendencies, with special emphasis on stylistic traits typical of Lysippos' times. Evidence in support of this date can be found, I believe, in the compositional pattern of the Jason and his alleged three-dimensionality; but in order to prove my point I must first outline the nature and evolution of sculptural patterns.

By pattern I mean the linear scheme underlying a composition in the round. In modern terms, this scheme might correspond to the preliminary outline sketch, drawn on paper, on which the artist will base the statue to be carved. Such a pattern is usually lost to conscious observation once the work has reached its three-dimensional shape. It can often be recovered by looking at a photograph of the piece, since a photograph by necessity flattens all forms into one plane and brings out once more the outline initially conceived.

In archaic and classical sculpture the pattern is usually a single one, and coincides with the frontal contour of the statue which makes the shape or the action involved intelligible. From a lateral point of view the pattern is lost from sight and the composition becomes almost incomprehensible. Fron-

27 Hellenistic Sculpture, $4 \mathrm{I}$.

28 Pp. I75-I 77 .

20 "Tarentinische Knöchelspielerinnen," MusHelv I6 (1959) 29-58, passim; esp. p. 55. For Dörig's work on Lysippos, see also his "Ein lysippisches Heraklesköpfchen in Basel," $A M \quad 7 \mathbf{I}$ (1956) I80-192, and "Lysipps letztes Werk," Jdl 72 (1957) 1943. tally seen, for instance, Myron's Diskobolos (pl. 37, fig. 8) reveals the system to which the entire statue can be reduced: a series of empty triangles enclosed by the zigzagging line of the body and topped by the balancing arc of the arms. Artificial as this scheme may seem, it is successful in creating an illusion of rhythmical motion and in conveying the intended action. From a point of view lateral to the base, however (pl. 37, fig. 9), the pattern becomes invisible, the statue appears drastically reduced in width, and the composition, besides lacking spatial depth, is almost unrecognizable. The bronze Zeus from Cape Artemision ${ }^{30}$ provides another striking example. Here the outspread arms and legs form a significant frontal silhouette of great power and majesty, but their impact is all but lost when the figure is viewed from the side. In spite of their vigorous gestures, compositions of this type and period expand only in one plane coincidental with the axis of the body; regardless of their physical third dimension as figures in the round, such statues lack artistic depth and for aesthetic purposes can be termed two-dimensional.

This sculptural difficulty is eliminated by the formulas of torsion and space-enclosure devised by Lysippos and his followers. It would therefore seem at first that in moving from two-dimensional to three-dimensional compositions, Greek sculpture should be free from dependence on pattern, and that an interest in voids and masses should replace experimentation with linear schemes. I maintain, however, that patterns, far from disappearing, merely become more complex and numerous. Since a Hellenistic work can be viewed from many positions, its schemes may vary accordingly and may be as many as the points of view, with perhaps one aspect more expressive, and therefore more emphasized, than the others. This would be the case, for instance, in the explosive composition of the Barberini Faun, ${ }^{31}$ or in some of the Gauls from the Pergamene dedication, ${ }^{32}$ where the limbs stretch into space radiating from the roughly polygonal contour of the body. Or a pattern can remain the same in spite of the multiplicity of satisfactory views. This scheme is particularly appropriate for

\footnotetext{
${ }^{30}$ Lullies \& Hirmer pls. I28-129. The flatness of the pose is not imposed by athletic rules and practices. In real life, the actions of discus- and javelin-throwing would determine a more torsional and three-dimensional stance.

31 Bieber figs. 450-451.

32 Notably the one in Venice, Bieber fig. 430.
} 
pyramidal compositions such as the crouching Aphrodite by Doidalsas ${ }^{33}$ (where the spiral torsion in space has given way to a fairly frontal folding and doubling up of the body), or the KnifeGrinder in the Uffizi, ${ }^{34}$ whose compact structure is unified by the course of the arms imprisoning the knees.

These two trends in the application of patternthe kaleidoscopic which allows many forms and many views, and the over-all which emphasizes one shape from all sides-also prevail in group compositions. $^{35}$ Both types of pattern, no matter whether employed for a single figure or for a group, impart a considerable three-dimensional appearance to the whole. Even in some apparently simple monuments, where the pattern can be reduced to a broken zigzag line mostly noticeable from the frontal view, the result is far from the flat rendering of the classical period. ${ }^{36}$

This interest in three-dimensionality was followed, however, by a reactionary return to more flattened compositions: not the simple unavoidable renderings of fifth century works which were truly two-dimensional and strove to appear three-dimensional, but a sophisticated attempt to present an essentially three-dimensional scheme in an actually two-dimensional pose, by drastically reducing the statue's depth in space. ${ }^{37}$ This intentional re-

${ }^{33}$ Bieber figs. 290-293.

34 Bieber figs. 44I-442. G. Krahmer's article "Stilphasen der hellenistischen Plastik," $R M$ 38/39 (1923-24) I38-189, with its emphasis on pattern, is of fundamental importance for my discussion, although occasionally I find myself at variance with some of the author's conclusions.

35 The first type appears for instance in the Gaul killing himself and his wife (Bieber figs. 281-283); the male figure is in complete torsion, the abrupt turn of his head and the swing of the mantle underlining his motion, while the limp body of the woman introduces a counter-movement and a different direction into the composition. The second type is exemplified by the so-called Pasquino group, with Menelaos holding the body of Patroklos (Bieber figs. 272-275). The theme of the work, playing on the same contraposition of vital and lifeless forms, is similar to that of the Ludovisi Suicidal Gaul, yet the general outline of the piece is continuous and on every side it rises from bottom to top in a pyramidal scheme. The Boy strangling the Goose (Bieber fig. 285) and the Uffizi Wrestlers (Bieber fig. 267) are two interesting examples of this same use of pattern, the former because of its extreme simplicity of forms, the latter because of the extreme elaboration of the interlocking limbs.

${ }^{36}$ As interesting contrast to Myron's Diskobolos one may consider for instance the Nike of Samothrace (Bieber figs. 493496) or the Aphrodite of Melos (Bieber figs. 674-675). In them each section of the body stretches in its own direction and forms a counterpart to the section immediately preceding or following; but this movement is not confined to a single shallow turn to classical "shortcomings" finds its parallel in the "archaizing" movement, which reverted to archaic formulas imbued with Hellenistic sophistication. The two trends are contemporary and are the logical result of the eclectic tendencies of the last century before Christ, when true artistic creativity had been drained and technical ability was channeled into subtle adaptations of bygone forms.

This phenomenon was first pointed out by $\mathrm{E}$. Schmidt, ${ }^{38}$ whose basically correct observations were marred by his conclusion that the flatness and two-dimensionality he noticed in several late-Hellenistic works were due to their pictorial origin. G. Krahmer convincingly refuted such a theory by remarking that the sculptor could always introduce three-dimensionality in his works, should he so desire, even though deriving his inspiration from a painting and translating a flat representation into a monument in the round. In an article which remains a classic of archaeological analysis ${ }^{39}$ Krahmer examined several group compositions, all characterized by considerable lack of depth in spite of complicated poses. $\mathrm{He}$ dated them in the last phase of the Hellenistic period, as representative of a tendency toward flatness and onesidedness prevalent not only in groups but also in single statues. ${ }^{40}$

area within which the body appears unnaturally compressed, as in the case of the Diskobolos; nor does the body spiral around a central vertical axis, as in the Vatican Apoxyomenos. In these Hellenistic compositions each section is thrust obliquely forward and backward into space, with the result that the same zigzagging motion can be observed from the sides as well as from the front of the figures. See also Carpenter, p. 201 .

37 This statement by no means implies that more "plastic" compositions did not continue to be sculpted side by side with these two-dimensional renderings.

38 "Über einige Fälle der Übertragung gemalter Figuren in Rundplastik," Festschrift Paul Arndt 96-I 14.

39 "Die einansichtige Gruppe und die späthellenistische Kunst," NGG Phil-Hist. Kl. (1927) 53-91. For the statement mentioned above see esp. 56-57.

${ }^{40} \mathrm{He}$ was led to this chronology by what, at the time, was considered the unshakable position of the Laokoon in the first century B.c. Although we now know that this assumption was erroneous, Krahmer's analysis of the group was correct, being based on its appearance after its modern restoration. The new arrangement of the work along its original lines has added depth and three-dimensionality to the composition, thus justifying and supporting a revised dating; see F. Magi, "Il Ripristino del Laocoonte," MemPontAcc 9 (1960) 36. But even if Krahmer's premises were incorrect, his conclusions are still valid and apply to the other Hellenistic works mentioned in his article. 
This argument has recently been revived by $\mathrm{H}$. Weber ${ }^{41}$ who assigns the originals of the Niobids in Florence to the first century B.c. on the basis of their essential relief-like quality, the diagonal axis of their compositions, their isolation as individual figures in spite of the implied presence of other participants in the story, and their display of musculature and drapery in motion which makes them veritable "Bewegungsstudies." ${ }^{42}$ According to Weber, the very traits reminiscent of fourth century art which had generally prompted the attribution of the statues to the post-Praxitelean or post-Scopasian phase confirm his revised chronology. This connection of early and late features, this combination of late Hellenistic formulas with stylistic forms proper to the end of the fourth century, typify the eclectic production of the first century B.C., although it had several forerunners in the second half of the second century.

If, as I believe, the foregoing remarks are correct, and such return to two-dimensional patterns was a dominant feature of late Hellenistic sculpture, I submit that the date of the Jason should be revised accordingly.

The formula of one arm carried across toward the other has been associated so firmly with a three-dimensional effect that its use in the Jason has never, to my knowledge, been questioned. Yet when the composition is viewed directly in front of the youth's chest the figure appears remarkably narrow. This reduction in depth is uncharacteristic of a Lysippean piece, and almost recreates the effect of Myron's Diskobolos or the Artemision Zeus. The profile view of the Sandalbinder's body builds an interesting and intelligible pattern: a long, slowly curving line from head to foot; in contrast, its frontal outline is virtually nonexistent, and from the front the work is uninteresting and seems almost built up in relief technique. ${ }^{43}$

This remark will be more clearly understood if the Jason is examined with other pieces of presumed Lysippean origin, or at least dating from

\footnotetext{
41 "Zur Zeitbestimmung der florentiner Niobiden," JdI 75 (1960) II $2-132$.

42 op. cit. $\mathrm{I} 25, \mathrm{I} 26, \mathrm{r} 32$.

43 In this context, front and profile refer to the statue as a representation of a human body, and not as a composition meant to be viewed from a specific angle. Thus the front of the body means the side of the base, and vice versa.

44 Bieber fig. 87.

45 Bieber fig. ro3.
}

the end of the fourth and the beginning of the third century в.c. Aside from the Apoxyomenos, there are other statues which employ the same formula of outstretched converging arms, but with entirely different results. We can see it, for instance, in the Eros stringing his bow, ${ }^{44}$ where the spiraling stance of the body echoes that of the Vatican athlete. Even more cogent is the contrast with the Ares Ludovisi; ${ }^{45}$ undeniable similarities with the Jason in bodily proportions and position of the arms only emphasize the fact that the seated figure, which also forms an interesting pattern from the side, is still equally intelligible and correctly proportioned from the front.

Besides the position of the arms, the raised foot of the Sandalbinder has been responsible for his Lysippean label: the Sikyonian master is in fact credited with several works exploiting this compositional motive. Perhaps the most plausible attribution is that of the Lateran Poseidon, ${ }^{46}$ which is supposed to reflect the Poseidon Isthmios created by Lysippos for the Corinthians. ${ }^{47}$ The god rests his right foot on an elevation ${ }^{48}$ and one of his elbows leans against the bent knee, but here all similarities with the Jason's pose end. The divinity is represented almost frontally, with his left arm holding the trident in a line approximately parallel to the weight-carrying leg and the front edge of the base; the composition appears essentially "open" and equally proportioned from all points of view.

Another work often ascribed to Lysippos is the so-called Alexander Rondanini in Munich. ${ }^{49}$ The figure, probably once shown mounting a chariot, has been restored in the act of anointing himself. This restoration is wrong, although compatible with the surviving stumps of the arms, but the mistake of the modern restorer has the advantage, in this case, of making the statue even closer in pose to the Jason. Yet the Alexander appears in a more pronounced torsion, a more open three-quarter stance, and from no angle is the figure as narrow as the Sandalbinder. Some scholars maintain that the original of the Rondanini piece should be at-

\footnotetext{
$46 \mathrm{BrBr} 243$.

${ }^{47}$ Lucian, Zeus Trag. 9, cf. Lange 31-47; Johnson I42-149; Bieber 34 .

48 Originally probably a rock, in the Lateran piece replaced by a modern ship's prow. See the cast, with modern additions removed, in G. Q. Visconti, "Recenti restauri di sculture antiche nel Museo dei Gessi dell'Università di Roma," $\mathrm{ArchCl}$ I (1949) 72-73, pl. 2 I:2.

$49 \mathrm{BrBr} 105$.
} 
tributed to Leochares or Euphranor, and not to Lysippos; in either case, a date in the second half of the fourth century is suggested for its prototype, confirming the assumption that three-dimensional poses and open forms were favored at that time, inside or outside the Lysippean circle. Another work can perhaps be more confidently assigned to one of Lysippos' pupils, Teisikrates: the portrait of Demetrios Poliorketes, as exemplified by the bronze statuette in Naples, Nat. Mus. I606. ${ }^{50}$ Here again the general effect is far from that of the Jason, and the open and three-dimensional character of the bronze is especially significant in view of its predominantly profile stance. It would indeed seem that only statues copying the Jason, or derived from it, share with it this peculiar relief-like quality, which-as the above-mentioned examples illustrate -is not intrinsic to the general pose of the figures.

The flat rendering of the Jason cannot be explained by arguing that its compositional scheme has a pictorial rather than a sculptural origin. This argument has already been answered by Krahmer in a controversy with E. Schmidt. ${ }^{51}$ It is however true that sandalbinders are found in painting and in relief sculpture long before they appear in the round. ${ }^{52}$ But a comparison with two examples from the Parthenon frieze ${ }^{53}$ shows that the fifth century figures use both hands to tie their shoes, while the Jason, with his left arm resting on his knee, introduces a three-dimensional element typical of the Lysippean style, although preserving at the same time his two-dimensional scheme. Moreover, this linear, drawing-like quality is by definition typical of any pattern, and the only valid criterion remains the use made of the pattern itself. Myron's Diskobolos is a truly flat composition which tries, through its scheme, to look three-dimensional; the Jason is actually three-dimensional in pose, yet emphasizes its two-dimensional aspect. It should be further noted that other reliefs employ the same general motive of sandalbinding, yet-like their contemporary counterparts in the round-strive to appear steeped in space. The most famous example is perhaps the fifth century Victory untying her shoe from the Nike parapet on the Akropolis. ${ }^{54}$ The deep pockets of shadow formed between her

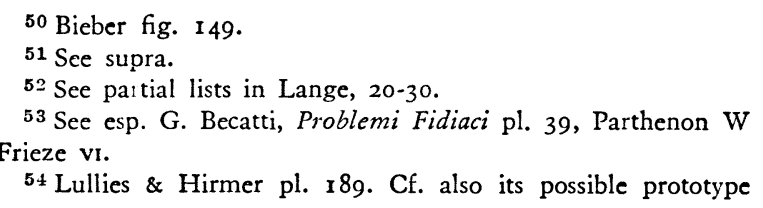

legs by her garment emphasize the distance between the two legs, and create an impression of depth and torsion. This is continued by the line of arms and shoulders, and must once have been made more pronounced by the presence of large wings. In spite of the relative shallowness of the relief, its general effect is almost more three-dimensional than that of the Jason, a composition in the round.

In some cases one may wonder whether the reverse applies, whether a relief has been inspired by a famous statuary prototype. Such a suggestion is advanced, for instance, by Charles Picard apropos of a Delian relief illustrating an Eleusinian legend, and on which Hermes appears in the general stance of the Sandalbinder. ${ }^{55}$ Since the relief seems to date from the beginning of the Hellenistic period, a Lysippean "Jason" could have been its model; yet the French scholar himself adds that perhaps the motive derives from the silhouettes of ephebes on the Parthenon frieze. ${ }^{56}$ In other instances, however, the resemblance between a relief figure and a statue is so striking as to be undeniable. This is true, for example, of the so-called Polyhymnia type, which appears in the "Apotheosis of Homer" by Archelaos of Priene, ${ }^{57}$ and is closely paralleled by a statue from the Esquiline in the Conservatori Museum. ${ }^{58}$ Several replicas of this are extant, thus proving the independent existence of the original monument in the round. In fact, it is now generally believed that Archelaos took his inspiration from earlier freestanding compositions.

The statue of the Muse, however, possesses the relief-like quality of the Jason. Polyhymnia stands leaning on a tall pillar which conceals almost the entire front of her body, while she appears to the spectator in a pronounced profile stance. An unbroken s-shaped contour line runs from the crown of her head to the heel of her left foot. The whole composition is remarkable for its reduced depth and for its compactness, which makes the monument almost unintelligible when the human figure is viewed from any position other than in profile. Indeed the Muse was chosen by Krahmer as a typical example showing that one-sided compositions existed not only in groups but also in contem-

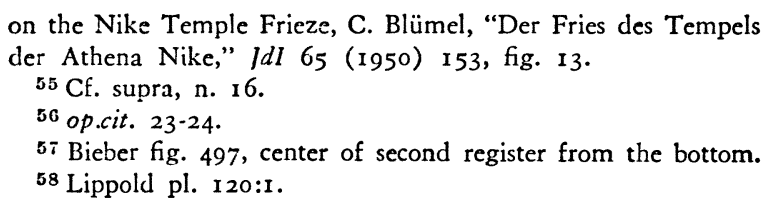


porary isolated statues. ${ }^{59}$ The "Apotheosis of Homer" is usually dated toward the end of the second century, and the original of the Esquiline Muse around 150 B.C.

Similar instances of "flat" compositions can be found among female figures which I have included as variants of the Jason-motif. ${ }^{60}$ I shall discuss in particular my nos. 5, 6 and 7 , because they are considered Hellenistic originals. No. 5, the so-called "Tiber statue," represents a woman who could be variously identified as a Muse, a nymph, a personification of some sort, or perhaps even as Aphrodite or Hygieia, to judge from similarly posed figures in Greek statuary repertoire. She is headless, ${ }^{61}$ her stance a mirror-image of the Jason's; her body is entirely covered by drapery. B. Neutsch ${ }^{62}$ describes her in unequivocal terms. Her clearest view is in profile, he affirms, "wenn sich die Gestalt fast nach Art eines à jour-Reliefs in der Fläche ausbreitet," while "im übrigen verrät jedoch die schmale Vorderansicht eindeutig die relief-harte Gesamtstruktur der Plastik." ${ }^{63}$ In chronological terms "reliefansichtige Komposition und geometrisches Formengerüst, Proportion mit schmalem Oberkörper, Raffinement des Gewandstils, sonstige Formensprache und Einzelzüge lassen erkennen, dass ihr Schöpfer dem späten Hellenismus kaum vor Ausgang des zweiten Jahrhundert v.C. zugehören muss." ${ }^{4}$

Similar to the Tiber statue, although in reversed pose, is a figure from Rhodes, my no. 6. Like the Jason, her right foot rests on a rock and her arms are crossed. She also is headless, but only the lower part of her body is covered by a mantle. G. Jacopi does not openly define the monument as relief-like, but he points out the pronounced onesidedness of the composition: "Il ritmo chiastico e complicato si presta apparentemente a una grande varietà di piani e di vedute, ma in realtà ciò non

\footnotetext{
$59 \mathrm{Krahmer}$, op.cit. (supra, n. 39) 67; cf. his figs. 5-6 on pl. 2. He calls the Polyhymnia "ein Werke ... das ganz flächig angelegt ist," whose main view coincides with its widest expanse and constitutes the only possible angle from which to view it. The composition is impossible from other sides. 60 See supra.

61 Her right arm, 1. forearm, r. foot with the corresponding parts of the drapery, and the last three toes of the raised foot are also missing.

62 "Weibliche Gewandstatue in römischen Kunsthandel," $R M$ 63 (1956) 46-55.

63 Pp. 49-50. Neutsch assumes however that this relief-like quality lies in the nature of the motive, which, he believes, can never entirely lose its derivation from "flat-art" (p. 47). On the contrary, I think that full responsibility for a three-
}

è che un'illusione ingenerata nell'osservatore dalla disposizione in profondità degli arti superiori: difatti non appena ci dicostiamo dalla veduta principale per girare attorno alla statua, sparisce la bella proporzione delle membra e l'accurata esecuzione del panneggio, e non rimane altro che un gioco di masse che sembra dettato da una concezione totalmente diversa, quasi impressionistica." ${ }^{65}$ Similar comments are made about the armed Aphrodite from Milan, no. 7, a headless figure whose heavy himation largely uncovers the feminine body. A. Frova writes: ${ }^{66}$ "Invece del ritmo spiraliforme a tre linee spezzate che provoca una forte ancheggiatura, la nostra statua, malgrado la sua torsione, sta su un asse piuttosto diritto e rigido secondo una costruzione apparentemente bidimensionale, con una veduta frontale un po' piatta, mentre 'gira' meglio nella veduta di tre quarti sulla sinistra, in cui risalta lo spostamento della destra e la torsione, e si presenta dinamicamente nelle due vedute laterali, quasi piani paralleli." Frova finds the Aphrodite difficult to place chronologically, but tentatively suggests a date in the second century B.c., based on some analogies with Rhodian works. ${ }^{67}$ In his turn, Jacopi considers his Rhodian Muse (no. 6) a postLysippean product of the local school which flourished from the third to the first century B.c. Neutsch, who mentions the Rhodian figure among the variants of his "Tiber statue," labels it a second century variant from a Lysippean prototype.

This prototype is however probably not the Jason, but a female figure sometimes attributed to the Sikyonian master and his circle, ${ }^{68}$ mostly on the basis of her pose with a raised foot: the Melpomene represented by replicas in the Vatican, Copenhagen and Stockholm. ${ }^{69}$ The statue in the Vatican was found in 1774 at Tivoli, in the Villa of M. Brutus, together with six other figures of Muses and an Apollo, besides many other ancient sculptures. The

dimensional or a two-dimensional rendering lies with the Hellenistic sculptor.

64 op.cit. 54.

65 ClRh 5:I (I93I) 6.

66 "L'Afrodite-Musa di Milano," $B d A 39$ (I954) S. Iv, p. I03.

67 ibid. 104.

${ }^{68}$ See Lange 57-62; Dörig, MusHelv (supra n. 29) 55.

${ }^{69}$ Rome: Lippold, Vat. Kat. III:I, Sala delle Muse no. 499, pp. 2I-24, pl. 4; Copenhagen, Ny Carlsberg Glyptotek no. 392 inv. Nr. 1565, Poulsen, Cat. p. 262; EA 4596; Stockholm, O. Antonsson, Antik Könst (Stockholm 1958) fig. at p. 19; $E A$ 4951. For other replicas and variants see also Neutsch, op.cit. (supra, n. 62) and Mustilli, Museo Mussolini, pp. 67-68, no. 9, and their lists. 
group of Apollo and the Muses was considered a stylistic unit after early third century originals. This is the opinion expressed for instance by Otto Brendel in his text to $E A 4596 ; 7^{70}$ and Lippold ${ }^{71}$ dates the group about one generation after Praxiteles, though he does not fail to notice the relieflike quality of the Melpomene. ${ }^{72}$ More plausibly, Schuchhardt ${ }^{73}$ suggests that the grouping was created by Romans after originals of different periods remotely reminiscent of classical works, but none earlier than the Hellenistic era. Similarly Poulsen, ${ }^{74}$ commenting on the Copenhagen Melpomene, affirms that "the very mixed style traits in this and related figures rather suggest a much later period, the Ist century B.c. or the beginning of the Roman period."

This last dating is however later than the chronology I propose for the Jason. Indeed, in looking at the Melpomene, one is struck by the lifeless quality of the statue and the almost forced flatness of the pose: the position of the body is essentially frontal, yet the head, the raised foot, and the bent knee and arm are fully in profile, so that the right half of the composition appears almost divorced from the left or simply juxtaposed to it. This is a veritable tour de force characterized by the exaggeration which usually accompanies the final, almost exhausted phase in the exploitation of any formula or motive. The second century introduced relief-like compositions with two-dimensional aspects which the first century в.c. developed to tasteless excess. Against the uninspired Melpomene the Jason appears a novel and forceful masterpiece.

One might argue that some of the excessive flatness of the Muse is due to the garment that stretches like a thick curtain between the legs and emphasizes the unbroken expanse of the frontal aspect. ${ }^{75}$ But male naked figures exist which display a similar reduction of compositional depth.

70 Also $E A 4607$ and 4608 ; see esp. col. 34 for comparisons with early third century works.

71 Vat. Kat., op.cit., see esp. p. 68.

72 "Der r. Fuss ist gerade nach vorn, der 1. rechtwinklig dazu zur Seite gerichtet, zwischen beiden Seiten fehlt jede Vermittlung ... Infolge der gewaltsamen Drehung des 1 . Beines bleibt die Komposition des Ganzen stark reliefmässig, mit Betonung der Vorderansicht," op.cit., p. 23.

73 op.cit. (supra p. II 7 , bibliography of no. I) 183 .

74 Cat. p. 262.

75 Indeed, Neutsch, op.cit. 47, asserts that in female statues the relief effect is even more concrete than in male figures because of the drapery filling the space between the legs.

76 Supra.

77 Bieber figs. 422, 688-689.
I have already mentioned ${ }^{76}$ Weber's remarks on the Florentine Niobids. It is interesting to note that some of the sons of Niobe are indeed shown in what could be termed an exaggeration of the Jason's pose, with raised foot and strongly diagonal body. It is also significant that the Delos Warrior and the Borghese Fighter ${ }^{77}$ should be indicated as second century prototypes for such rendering.

That the Jason resembled the Borghese Warrior was noticed by Gavin Hamilton, who discovered the Copenhagen replica of the Sandalbinder in I769, and his remark is quoted by Michaelis in his description of the piece when it was in the Lansdowne collection; Fröhner also mentions this similarity apropos of the Louvre replica. Many scholars have since made the same comparison, and found in it proof for ascribing the Jason to Lysippos' school rather than to the master himself. This inference was however based on the belief that the Fighter was also an early third century work. Since our present knowledge seems to indicate that Agasias sculpted the Warrior in the period of the Lysippean revival, toward the end of the second century, ${ }^{78}$ there are only two alternatives open to the advocates of such similarity: either the Borghese Warrior itself should be considered "a copy, translated into late Hellenistic style, from an original by the sculptor of the Jason," should be brought down to the period of the statue in the Louvre. ${ }^{80}$

The first alternative has perhaps been already refuted by Carpenter, ${ }^{81}$ who affirms that "whether Agasias copied in marble another master's work in bronze or, alternatively, transmuted some earlier (e.g. Lysippan) statue into second-century form, the Warrior remains a second-century creation; and it is of no great moment whether we have this creation at first or second hand." The

\footnotetext{
78 Marcadé, Signatures II:2, lowers the date to the beginning of the first century B.C.

79 This is Johnson's position, p. I77.

80 There exists, of course, a third possibility: that the extant copies of the Jason have also been reworked in the manner of the late Hellenistic period. This thought is voiced by Dörig, MusHelv (supra, n. 29) 53. He admits that some of the Borghese Warrior's spirit can be felt in the copies of the Sandalbinder, though one must not exclude an early Hellenistic prototype. I do not share this belief, however, especially in view of the fact that all the adaptations and re-elaborations of the Jason-motif seem to convey the same two-dimensional effect and cannot be dated earlier than the second century B.c.

81 Pp. 220-22I.
} 
second alternative forms the entire thesis of the present paper.

Several points can be made to stress the similarity between the Fighter and the Sandalbinder. The most obvious is their common dependence on Lysippean formulas and stylistic traits. The elongated bodily proportions, the relatively small head, the facial features and the hair-rendering recall those of the Apoxyomenos and, in the Borghese Warrior, have been attributed to a conscious revival of earlier motives, ${ }^{82}$ in the Jason, to the normal artistic tendencies of early Hellenistic times. But nothing prevents us from also explaining as Lysippean revivals the Lysippean echoes in the Sandalbinder. The anatomical treatment of both figures seems to confirm this assumption. At first sight the body of the Jason appears conceived in moderate terms as contrasted to the violent rendering of the Louvre statue, which displays too exaggerated a realism (certainly aesthetically convincing, whether or not anatomically accurate) to be a true product of classical times. But an interesting insight is provided by the technique of the copyist who worked on the unfinished version of the Jason in Athens. In Blümel's words" "he lightened his task by means of numerous graphic sketches and covered the whole figure with them, like an anatomic study." This fractioning of the anatomy into bulges and valleys definitely recalls the extreme articulation of forms of the Borghese Warrior, whose "flayed" effect, it has been pointed out, "is due solely to the deeply grooved demarcations of the muscular divisions which make them preternaturally salient." I was able to examine the Jason torso in Athens and am convinced that the "swollen" appearance of the muscles is not caused merely by the unfinished state of the sculpture, but was part of the final intention of the sculptor.

Another trait which the Sandalbinder shares with the Fighter is the abrupt turn of the head. Agasias' Warrior is presumably looking up toward an invisible opponent attacking him on horseback; in the case of the Jason, if we accept Christodoros' explanation, Hermes is intently listening to Zeus' orders; if we are dealing with an athlete, something must have suddenly attracted his attention and made him stop tying his shoe. In all cases, both poses

\footnotetext{
82 See Bieber 162.

83 op.cit. (supra p. II6, bibliography of no. 3) 62 .

84 Carpenter, p. 220.

85 These comments apply also to the Florentine Niobids, as
}

imply another personage in the composition, thus transforming athletic statues into "genre" scenes. ${ }^{85}$

A final common point, perhaps not as readily apparent as those previously mentioned, is the underlying linear quality of both monuments. I have already discussed such linearity in the Jason, pointing out that it contradicts the three-dimensional formula of the pose. The Borghese Fighter also, as a composition, presupposes full knowledge of three-dimensional effects; indeed the statue seems to be the acme of three-dimensional art. Still there is an angle from which the Warrior is quite narrow in width. Another view reveals the main pattern underlying the pose. A comparison with the fifth century Artemision Zeus will illustrate the point.

In the Zeus, arms and legs spread out in different directions, but the plane of the composition remains the same. The pattern is visible, the statue significant and the action understandable only when the Zeus is viewed in profile. We have here a truly two-dimensional work. In the Borghese Warrior the limbs spread out not only in different directions but also into different planes, thus creating a truly three-dimensional work to be seen and enjoyed from many viewpoints. Yet from one angle in particular the Fighter appears as a continuous curving line from hand to foot. While the master of the Zeus has achieved a certain continuity of outline only in the upper torso of his bronze, the Hellenistic sculptor has managed to fuse the whole action into one integrated pattern: the statue's dependence on this pattern is not as great as for the Jason, but the one very powerful outline and the narrow width of the Warrior have a relief-like quality which is almost as pronounced as in the Sandalbinder.

One final point might deserve consideration. The Borghese Warrior is known to us through no other replica, while there are several reproductions of the Jason and numerous adaptations of its general stance, both in male and female figures. Could this abundance of copies reflect the popularity enjoyed among the Romans by an original of the "good period," creation of a famous master, as contrasted with a virtual indifference toward the patently Hellenistic statue by Agasias? ${ }^{86}$ The na-

\footnotetext{
remarked by Weber; see supra.

86 The excavators of the Jason's replica in Side state that all other works from the same complex copy famous statues
} of the fifth and fourth centuries B.c. (Mansel, Ruinen von Side 
ture of the statues themselves may supply the answer. Though the Romans were avid collectors of classical reproductions, they were not averse to copying Hellenistic originals. The many extant replicas of dancing satyrs and reluctant nymphs testify to that. But such works could easily be adapted for fountain-ornaments and were quite appropriate in the setting of Roman villas. Similarly, the Jason was the perfect decoration for a palaistra. The Fighter was perhaps too specific in the portrayal of a definite action, while the Sandalbinder, in its noncommittal pose, could represent any athletic activity. If the original creation indeed portrayed the god Hermes, a Hellenistic date would be more in keeping with the diffusion of his cult as patron of gymnasia and schools, ${ }^{87}$ and would explain the popularity enjoyed by the composition as a stock body for Roman portrait statues.

In summary, I suggest that the original of the so-called Jason is an eclectic second century work not far removed in time from the Borghese Warrior. The Sandalbinder's body shows the same bulging musculature which we see in Agasias' Fighter. More important, the pose of the Jason emphasizes

I 8 ). But some of the pieces, in my opinion, might go back to Hellenistic prototypes. the two-dimensional aspects of a composition which should be predominantly three-dimensional, and this characteristic is also present in all the variations and adaptations of the "Jason-pose," none of which seems to date earlier than the late Hellenistic period. By contrast, several other works also attributed to Lysippos or his pupils show a greater openness of forms and of movement in space, in spite of a general similarity of stance to that of the Sandalbinder. Narrow width of composition, relief-like quality, abrupt turn of the head, classical echoes, isolation and "genre" characteristics-traits which the Jason shares to a certain extent with the Louvre Warrior and especially with other figures from the middle of the second century B.c.- - seem to be compositional devices introduced at that time, which become even more pronounced and exaggerated in works of the last century before Christ. I therefore see in the Jason only vague echoes of Lysippean style, rather than the imprint of the great master himself or of his school.

BRYN MAWR COLLEGE

\footnotetext{
${ }^{87}$ See Nilsson, Geschichte der griechischen Religion I (Munich I94I) 47I-472.
} 


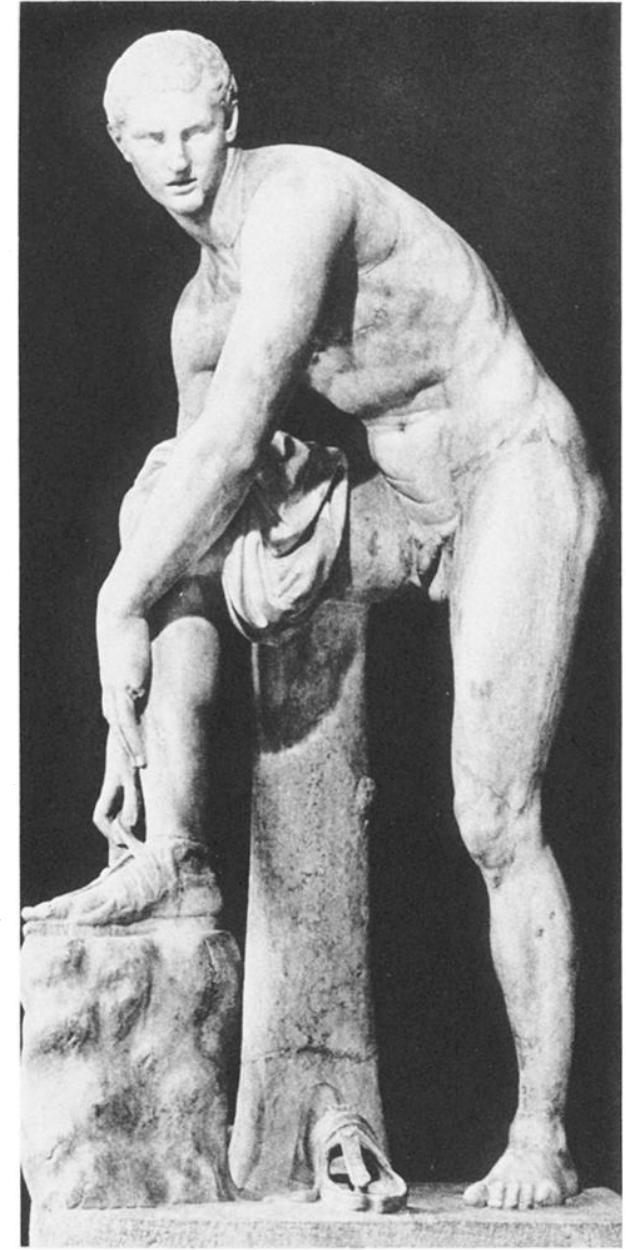

Fig. I. Paris. Louvre Jason, front view

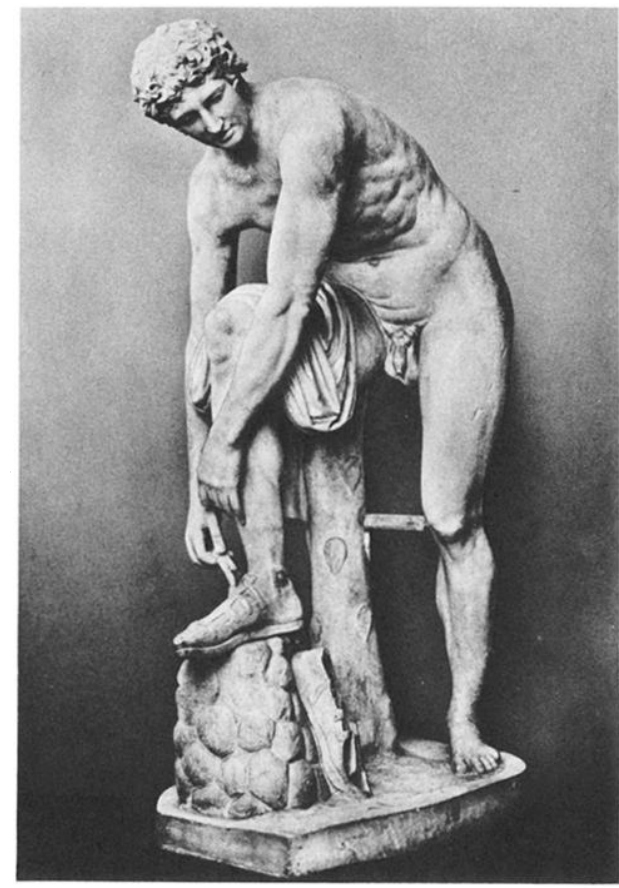

Fig. 3. Munich Jason, front view
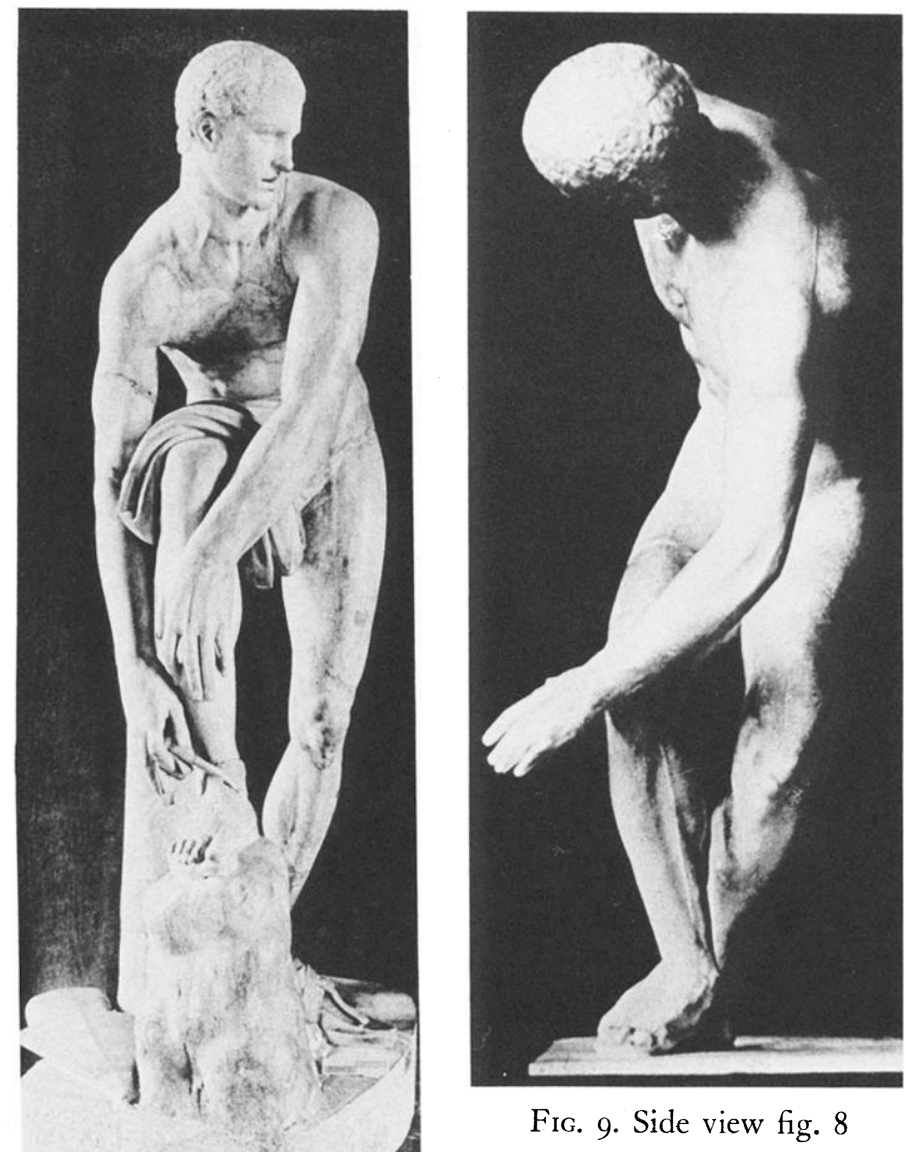

Fig. 9. Side view fig. 8

FIg. 2. Side view fig. I

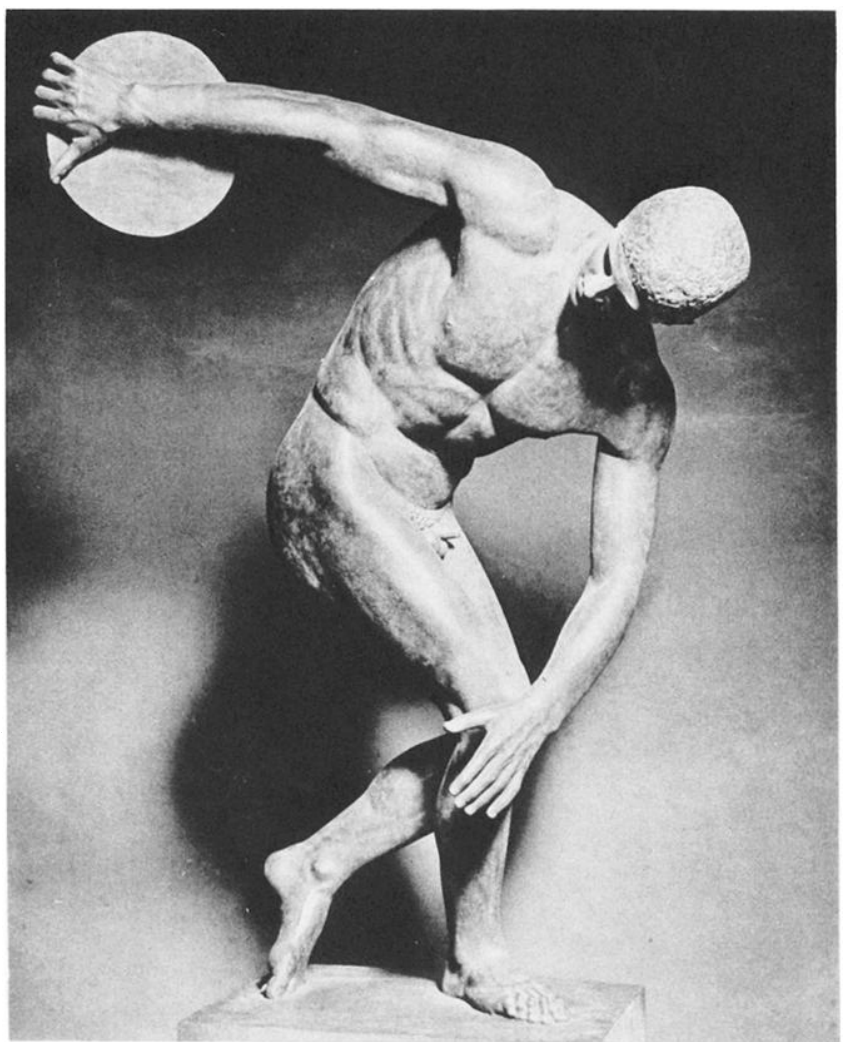

Fig. 8. Diskobolos (reconstruction), front view 

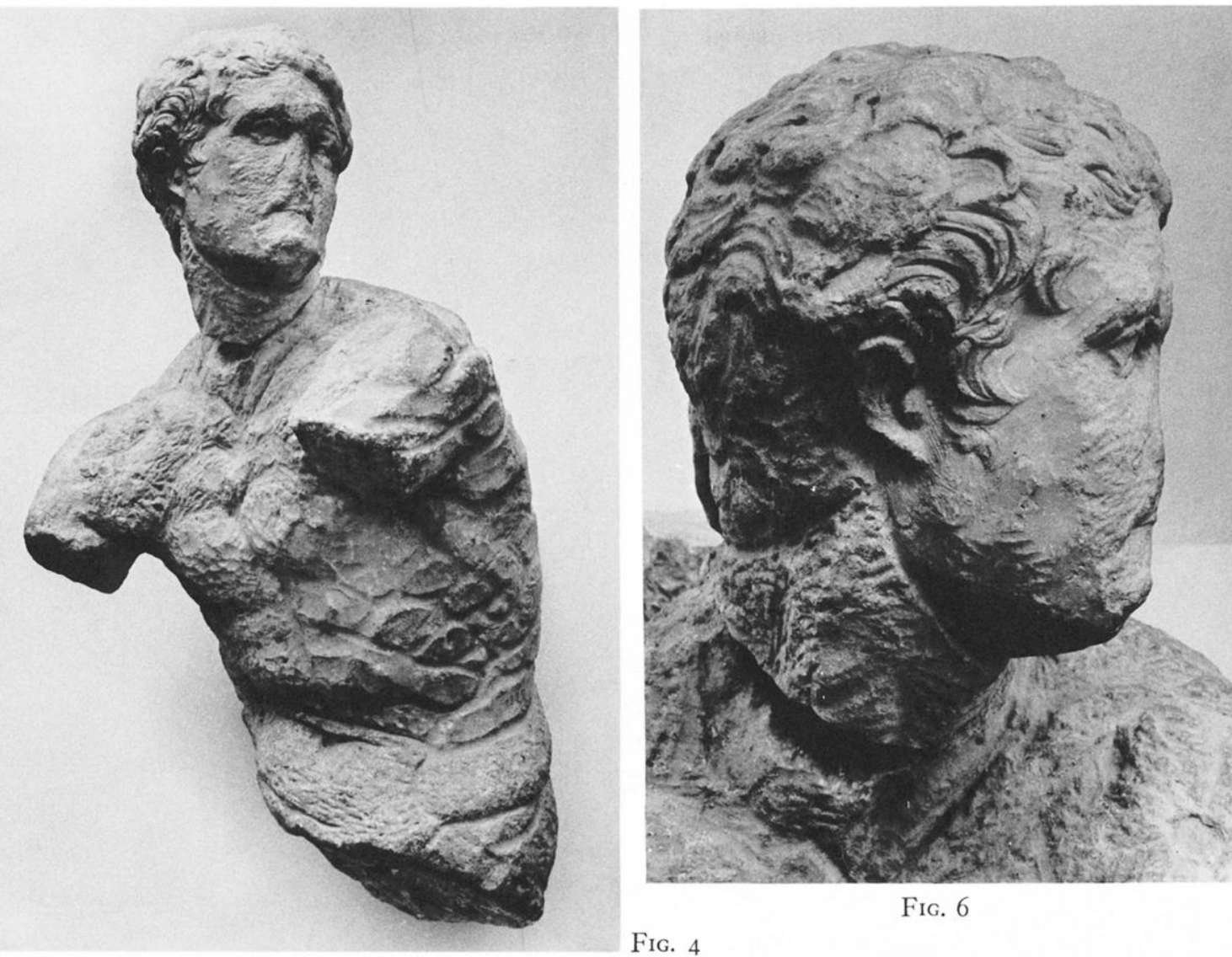

FIG. 6

Fig. 4
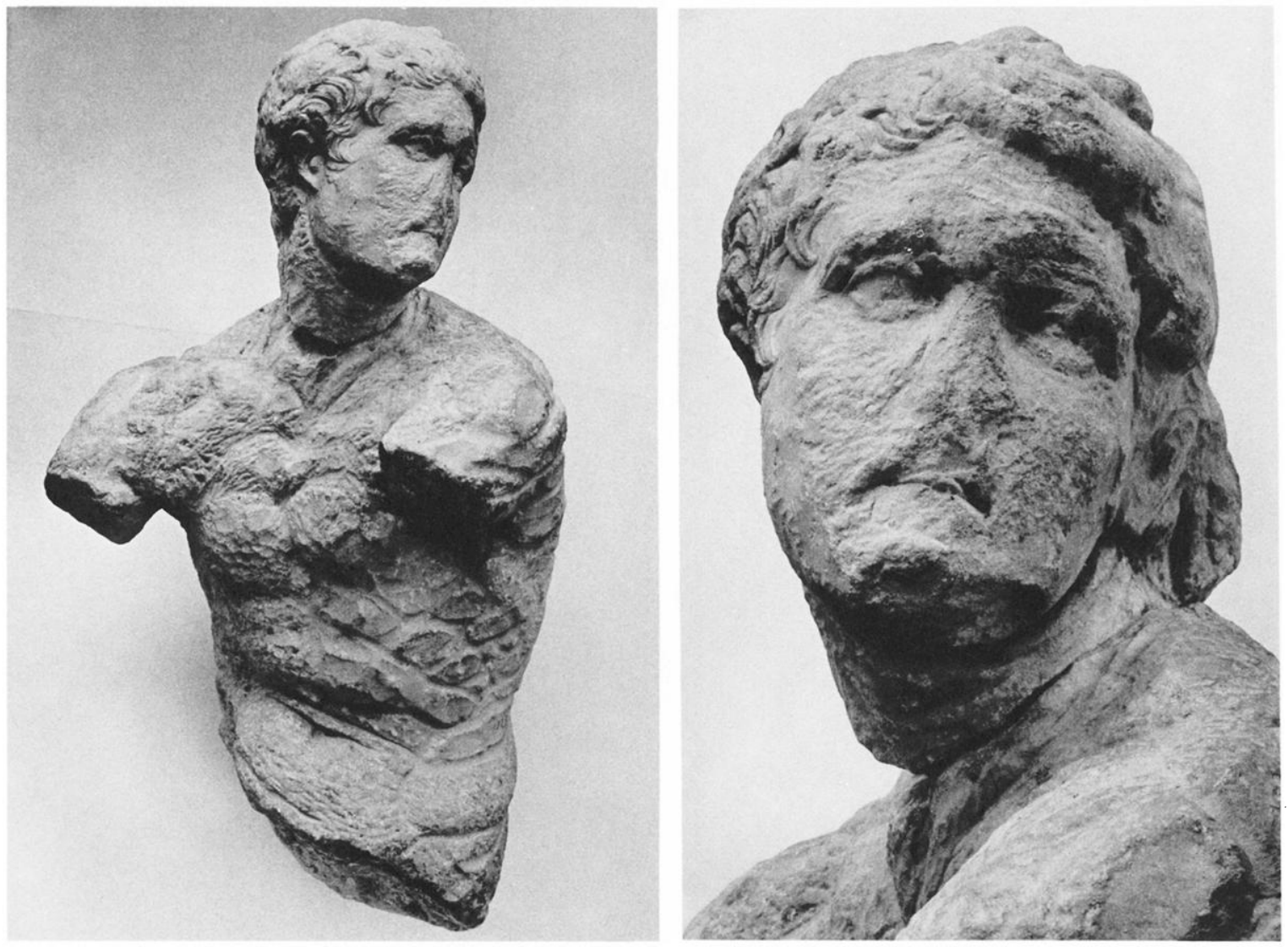

Fig. 5 Athens, Akropolis. Unfinished Jason

FIG. 7 